\title{
Correlation Between Levels of 25-Hydroxy-Vitamin D and Degree of Anemia in Patients with Chronic Kidney Disease
}

\author{
Elena López-Ramiro ${ }^{1}$, Mercedes Rubert ${ }^{1}$, Emilio González-Parra ${ }^{2}$, Ignacio Mahillo ${ }^{3}$, \\ Concepción de la Piedra ${ }^{1, *}$ \\ ${ }^{1}$ Biochemistry Laboratory, Sanitary Research Institute Jiménez Díaz Foundation, Madrid, Spain \\ ${ }^{2}$ Nefrology, Sanitary Research Institute Jiménez Díaz Foundation, Madrid, Spain \\ ${ }^{3}$ Epidemiology and Statistics, Sanitary Research Institute Jiménez Díaz Foundation, Madrid, Spain
}

\section{Email address:}

cpiedra@fjd.es (C. de la Piedra)

${ }^{*}$ Corresponding author

\section{To cite this article:}

Elena López-Ramiro, Mercedes Rubert, Emilio González-Parra, Ignacio Mahillo, Concepción de la Piedra. Correlation Between Levels of 25-Hydroxy-Vitamin D and Degree of Anemia in Patients with Chronic Kidney Disease. American Journal of Clinical and Experimental Medicine. Vol. 5, No. 4, 2017, pp. 151-156. doi: 10.11648/j.ajcem.20170504.18

Received: May 16, 2017; Accepted: May 27, 2017; Published: July 18, 2017

\begin{abstract}
Introduction: Vitamin D exercises pleiotropic effects independently of calcium and phosphorous homeostasis. Purpose: To analyze the possible correlation between levels of 25 -hydroxy vitamin D $(25(\mathrm{OH}) \mathrm{D})$ and other parameters of patients with chronic kidney disease (CKD). Patients and methods: One hundred and forty-five patients with stage-5 CKD were studied (mean age $65.9 \pm 14.6$ years; 74 males and 71 females; Levels of $25(\mathrm{OH}) \mathrm{D}$, age, bone alkaline phosphatase, procollagen I amino-terminal propeptide, carboxyterminal telopeptide of collagen I, intact parathyroid hormone (PTH), bioPTH, hemoglobin, hematocrit, urea, creatinine, total proteins, albumin, iron, iron saturation index, calcium, phosphorous, total alkaline phosphatase, serum $\mathrm{CO}_{2}$, cholesterol, triglycerides, C-reactive protein, prealbumin, ferritin, proBNP, and fibroblast growth factor-23 (FGF-23) were determined. Spearman's correlation coefficient and p values were analyzed. Results: This work show a positive correlation between levels of $25(\mathrm{OH}) \mathrm{D}$ and anemia (i.e., hemoglobin, hematocrit, iron, iron saturation index, and ferritin). Conclusion: These results show the close relationship between the degree of anemia in patients with CKD and $25(\mathrm{OH}) \mathrm{D}$ levels. It is of great importance to maintain levels of $25(\mathrm{OH}) \mathrm{D}$ in patients with advanced-stage $\mathrm{CKD}$, as this can decrease anemia levels and, in turn, lower quantities of erythropoietin would be necessary to maintain hematocrit.
\end{abstract}

Keywords: Hemodialysis Patients, 25(OH) Vitamin D, Anemia

\section{Introduction}

In recent years there has been a renewed interest in the effects that vitamin D status exerts on health. Although the efficiency of vitamin D status has been classically associated with bone pathology, the discovery that almost all body tissues and cells have vitamin D receptors (VDR) and an enzyme system to synthesize $1.25(\mathrm{OH})_{2}$ Vitamin D $\left(1.25(\mathrm{OH})_{2} \mathrm{D}\right)$ has evidenced that vitamin $\mathrm{D}$ carries out other functions such as inhibition of cellular proliferation, angiogenesis, and renin production, the stimulation of cellular maturation, and the regulation of immune response. For this reason, low levels of vitamin D are now associated with mortality, cancer, cardiovascular disease, autoimmune diseases, diabetes, psychiatric illness, and even respiratory disease in addition to the previously known effects on bone metabolism (osteomalacia, secondary hyperparathyroidism, osteoporosis, and fractures $[1,2]$.

In chronic renal disease in hemodialysis as many as $80 \%$ of patients present low concentrations of $25(\mathrm{OH})$ Vitamin D $(25(\mathrm{OH}) \mathrm{D})$ [3]. Besides the general causes producing low levels of vitamin D [4] in the population, in patients with renal disease, FGF-23 can produce an inactivation of $25(\mathrm{OH}) \mathrm{D}$ through the activation of 24-hydroxylase, which transforms it in 24, 25(OH) $)_{2}$ Vitamin D [5]. The KDIGO (Kidney Disease Improving Global Outcomes) guides recommended correcting this insufficiency by applying the strategies used in the general population [6]. In the first stage, 
the nephrologist focuses treatment with vitamin D on the prevention or treatment of secondary hyperparathyroidism [7], without taking into account its auto/paracrine effects. However, more and more attention is now being given to the extra-renal role that vitamin D levels play in patients with CKD.

The aim of this work is to correlate $25(\mathrm{OH}) \mathrm{D}$ levels in a group of dialysis patients with those of 26 other important parameters, in order to determine the extent to which these parameters may be determined by vitamin D (levels of 25(OH)D) status.

\section{Materials and Methods}

One hundred and forty-five patients with stage-5 CKD were studied (mean age $65.9 \pm 14.6$ years; 74 males vs. 71 females; mean time of dialysis of 3 years (p25: 2 years, p75: 6 years)) were recruited from the Dialysis Unit of the Jiménez Díaz Foundation hospital in Madrid and studied prospectively and observationally. An $85.1 \%$ of patients were with any activator of the receptor of vitamin $\mathrm{D}$, and $17.9 \%$ were receiving cinacalcet. The patient sample was the same studied in the work "Estudio de las diferentes formas de medida de parathormona sérica en el seguimiento del paciente en hemodiálisis. Influencia sobre la mortalidad. Importancia de las variaciones" by Laura Rodriguez-Osorio et al., Nefrología, doi: 10.1016/j.nefro.11.021. (Epub ahead of print)

This study was authorized by the Ethical Committee of the Jiménez Díaz Foundation hospital. Informed consent was not necessary due to anonymous handling of patient data.

The most exhaustive baseline study possible in all patients was conducted. Values of $25(\mathrm{OH}) \mathrm{D}\left(\mathrm{D}_{2}+\mathrm{D}_{3}\right)$ were determined by electrochemiluminescence in an Elecsys autoanalyzer (Roche). Intra- and inter-assay coefficients of variation $(\mathrm{CV})$ were $<7.5 \%$ and $<8 \%$, respectively. The sensitivity of the method was $3 \mathrm{ng} / \mathrm{ml}$. PTH was measured by two different methods: one with second- and another of with third-generation assays. Values of intact-PTH (iPTH) or PTH obtained with second-generation assays were determined by electrochemiluminescence in the Elecsys autoanalyzer (Roche). This method uses an antibody directed against the aminoacids $26-32$ of the molecule, and another that is directed against the 55-64 zone. Due to this fact, this method does not detect the carboxy-terminal fragments of the molecule, though it detects the PTH 1-84 and the fragments 7-84. Intra- and inter-assay CV were $<2.5 \%$ and $<3 \%$, respectively. The sensitivity of the method was $1.2 \mathrm{pg} / \mathrm{ml}$. PTH values obtained from third-generation assays, PTH-bio, were determined by electrochemiluminescence in the Elecsys autoanalyzer (Roche). This method uses an antibody directed against the aminoacids 1-4 of the molecule, and another directed against the 55-64 zone, measuring only the molecule $1-84$. Intra- and inter-assay $\mathrm{CV}$ were $<3 \%$ and $<$ $6 \%$, respectively. The sensitivity of the method was 5.50 $\mathrm{pg} / \mathrm{ml}$. Hemoglobin and hematocrit were performed in an ADVIA 120 (Siemens). Hemoglobin is calculated by the method of cianmetahemoglobin modified, that measures the absorbance in a flux cuvette by colorimetry at $546 \mathrm{~nm}$. The hematocrit is mathematically calculated. Erythrocytes $\mathrm{x}$ corpuscular mean volume/10. With the ADVIA CENTAUR 2400 autoanalyzer were determined the following parameters: serum albumin (bromocresol dye-binding method), intra- and inter-assay $\mathrm{CV}$ were $<1.3 \%$ and $<2 \%$, respectively. The sensitivity of the method was $1 \mathrm{~g} / \mathrm{dl}$; serum calcium (arsenazo III technique), intra- and inter-assay CV were $<1.2 \%$ and $<2 \%$, respectively. The sensitivity of the method was $0.5 \mathrm{mg} / \mathrm{dl}$; serum creatinine (alkaline picratetechnique), intra- and inter-assay $\mathrm{CV}$ were $<3.1 \%$ and $<4 \%$, respectively. The sensitivity of the method was 0.2 $\mathrm{mg} / \mathrm{dl}$; serum inorganic phosphate (phosphomolybdate UV technique), intra- and inter-assay $\mathrm{CV}$ were $<2.2 \%$ and $<3 \%$, respectively. The sensitivity of the method was $0.3 \mathrm{mg} / \mathrm{dl}$; serum total proteins (biuret technique), intra- and inter-assay CV were $<1.3 \%$ and $<2 \%$, respectively. The sensitivity of the method was $2 \mathrm{~g} / \mathrm{dl}$; C-reactive protein (PCR) (turbidimetric technique potenciated with latex), intra- and inter-assay $\mathrm{CV}$ were $<4.9 \%$ and $<6 \%$, respectively. The sensitivity of the method was $0.003 \mathrm{mg} / \mathrm{dl}$; serum alkaline phosphatase (p-nitrophenol hydrolysis), intra- and inter-assay CV were $<1.9 \%$ and $<2.4 \%$, respectively. The sensitivity of the method was $5 \mathrm{U} / \mathrm{l}$; serum urea (enzimatic reaction of Roch-Ramel, using urease and glutamate-dehydrogenase), intra- and inter-assay CV were $<1.1 \%$ and $<1.9 \%$, respectively. The sensitivity of the method was $4 \mathrm{mg} / \mathrm{dl}$; Iron was determined by colorimetry (ferric iron is dissociated from its transporter protein and is reduced to ferrous form. This form a complex with ferrocine, producing a chromophore), intra- and inter-assay CV were $<2.5 \%$ and $<$ $2.9 \%$, respectively. The sensitivity of the method was $2 \mu \mathrm{g} / \mathrm{dl}$; Ferritin (turbidimetric technique potenciated with latex), intra- and inter-assay $\mathrm{CV}$ were $<4 \%$ and $<5 \%$, respectively. The sensitivity of the method was $6.0 \mathrm{ng} / \mathrm{ml} ; \mathrm{CO}_{2}$ was analyzed by an enzymatic assay (reaction between phosphoenolpiruvate-carboxilase of $\mathrm{HCO}_{3}{ }^{-}$with phosphoenol piruvate to produce oxalacetate, intra- and inter-assay $\mathrm{CV}$ were $<2.2 \%$ and $<3.2 \%$, respectively. The sensitivity of the method was $5 \mathrm{mmol} / 1$; Serum cholesterol was determined by an enzymatic assay, intra- and inter-assay $\mathrm{CV}$ were $<0.7 \%$ and $<1.4 \%$, respectively. The sensitivity of the method was $5 \mathrm{mg} / \mathrm{dl}$; Triglicerides were determined by an enzymatic assay, intra- and inter-assay $\mathrm{CV}$ were $<0.6 \%$ and $<2.5 \%$, respectively. The sensitivity of the method was $0.1 \mathrm{mg} / \mathrm{dl}$. Serum prealbumin was determined in an SPA plus autoanalyzer by means of turbidimetry. Intra- and inter-assay $\mathrm{CV}$ were $<4.4 \%$ and $<6 \%$, respectively. The sensitivity of the method was $0.006 \mathrm{~g} / \mathrm{l}$. ProBNP was determined in a VITROS 5600 autoanalyzer, by an immunoassay by quimioluminiscence by MICROWELL technology, intra- and inter-assay $\mathrm{CV}$ were $<3.5 \%$ and $<6.0 \%$, respectively. The sensitivity of the method was $5 \mathrm{pg} / \mathrm{ml}$; fibroblast growth factor 23 (FGF-23), C-terminal, was measured by an enzyme-linked immunoassay (ELISA) (Immutopics, USA) using 2 polyclonal antibodies directed against the C-terminal 
fraction of FGF-23. Intra- and inter-assay CV were $<1.7 \%$ and $<3.5 \%$, respectively. The sensitivity of the method was $1.5 \mathrm{RU} / \mathrm{ml}$. Bone isoenzyme of alkaline phosphatase was determined in serum by ELISA (Ostase BAP, IDS, UK). Intra- and inter-assay CV were $<4.5 \%$ and $<6.4 \%$, respectively. The sensitivity of the method was $0.7 \mu \mathrm{g} / \mathrm{l}$. Serum aminoterminal propeptide of procollagen I (PINP) and carboxyterminal telopeptide of collagen I $(\beta-\mathrm{CTX})$ were measured by electrochemiluminescence in an Elecsys autoanalyzer (Roche). For PINP, intra- and inter-assay CV were $<2.9 \%$ and $<3.7 \%$, respectively. The sensitivity of the method was $5 \mu \mathrm{g} / \mathrm{l}$. For $\beta$-CTX, intra- and inter-assay $\mathrm{CV}$ were $<4.6 \%$ and $<4.7 \%$, respectively. The sensitivity of the method was $0.07 \mathrm{ng} / \mathrm{ml}$. Values of tweak were determined by ELISA (Bender MedSystems, Viena, Austria). Intra- and inter-assay $\mathrm{CV}$ were $<7.1 \%$ and $<8.3 \%$, respectively. The sensitivity of the method was $10 \mathrm{pg} / \mathrm{ml}$. Iron saturation index is a mathematic calculation: Serum iron $\mathrm{x} 100 /$ serum transferrin $\mathrm{x} 1.27$.

\section{Results}

Table 1 shows demographic and clinical characteristics and analytical values of the studied population. Of the 145 patients, 23 presented levels of $25(\mathrm{OH}) \mathrm{D}$ that were lower than $10 \mathrm{ng} / \mathrm{ml}, 39$ between 10 and $20 \mathrm{ng} / \mathrm{ml}$, and $53 \mathrm{had}$ values between 20 and $30 \mathrm{ng} / \mathrm{ml}$. With respect to values of hemoglobin, 30 patients showed values $<11 \mathrm{ng} / \mathrm{ml}$.

Table 1. Demographic and clinical characteristics and analitycal values of a population of 145 patients in hemodialysis.

\begin{tabular}{|c|c|}
\hline Variable & \\
\hline Age (years) & $65.9 \pm 14.6$ \\
\hline Time in hemodialysis (years) & Me 3 (P25-2, P75-6) \\
\hline Male $(\%)$ & 51 \\
\hline \multicolumn{2}{|l|}{ Hemodialysis technique (\%) } \\
\hline - Conventional & 90 \\
\hline - On-Line & 10 \\
\hline Hypertensión (\%) & 86.9 \\
\hline Diabetes Mellitus (\%) & 23.4 \\
\hline \multirow[t]{2}{*}{ Dyslipidemia (\%) } & 35.2 \\
\hline & $\mathrm{M} \pm \mathrm{DE}$ \\
\hline Hemoglobin (g/dl) & $11.8 \pm 1.6$ \\
\hline Hematocrit (\%) & $35.5 \pm 4.6$ \\
\hline Urea $(\mathrm{mg} / \mathrm{dl})$ & $117.7 \pm 36.5$ \\
\hline Total protein $(\mathrm{g} / \mathrm{dl})$ & $6.5 \pm 0.6$ \\
\hline Albúmin $(\mathrm{g} / \mathrm{dl})$ & $3.6 \pm 0.4$ \\
\hline Iron $(\mu \mathrm{g} / \mathrm{dl})$ & $65.4 \pm 28$ \\
\hline Iron saturation index $(\%)$ & $31.7 \pm 14.3$ \\
\hline Calcium (mg/dl) & $9.2 \pm 0.7$ \\
\hline Phosphorous (mg/dl) & $4.7 \pm 1.6$ \\
\hline $\mathrm{CO}_{2}$ & $21.4 \pm 3.5$ \\
\hline Cholesterol (mg/dl) & $158 \pm 35$ \\
\hline Prealbúmin (mg/dl) & $33 \pm 10$ \\
\hline Ferritin (ng/dl) & $406 \pm 242.1$ \\
\hline \multirow[t]{2}{*}{ Tweak (pg/ml) } & $319.2 \pm 275.1$ \\
\hline & $\mathrm{Me}(\mathrm{P} 25, \mathrm{P} 75)$ \\
\hline Bone alkaline phosphatase $(\mu \mathrm{g} / \mathrm{l})$ & $29.6(20.7,41.9)$ \\
\hline PINP $(\mu \mathrm{g} / \mathrm{l})$ & $255.3(161.2,486.6)$ \\
\hline$\beta-\mathrm{CTX}(\mathrm{ng} / \mathrm{ml})$ & $1.8(1.3,2.5)$ \\
\hline iPTH (pg/ml) & $205(116.5,386.1)$ \\
\hline Bio-PTH (pg/ml) & $119.5(76.2,240)$ \\
\hline
\end{tabular}

\begin{tabular}{ll}
\hline Variable & \\
\hline 25OH-vitamin D (ng/dl) & $22.9(12.7,34.2)$ \\
Creatinine (mg/dl) & $7.6(5.6,9.1)$ \\
Alkaline Phosphatase (UI/l) & $111(89,145)$ \\
Triglicérides (mg/dl) & $146(102,193)$ \\
C reactive protein $(\mathrm{mg} / \mathrm{dl})$ & $0.6(0.25,1.97)$ \\
ProBNP $(\mathrm{pg} / \mathrm{ml})$ & $8325(3422,17450)$ \\
FGF-23 $(\mathrm{RU} / \mathrm{ml})$ & $788(384,3258)$ \\
\hline
\end{tabular}

Table 2 shows Spearman's correlation coefficients and the corresponding $\mathrm{p}$ values of the studied correlations between levels of $25(\mathrm{OH}) \mathrm{D}$ and the rest of analyzed parameters. The results show a positive correlation with the parameters related with the degree of anemia of these patients. Hemoglobin $p<0.032$, hematocrit $p<0.051$, iron $p<0.003$, iron saturation index $\mathrm{p}<0.002$, and ferritin $\mathrm{p}<0.047$, as well as with creatinine $\mathrm{p}<0.044$, calcium $\mathrm{p}<0.020$, phosphorous $\mathrm{p}<0.041$ (negative correlation) and albumin $\mathrm{p}<0.041$, without correlation with the other analyzed parameters. Especially important is the fact that the correlations between levels of $25(\mathrm{OH}) \mathrm{D}$ and hemoglobin, hematocrit, iron, iron saturation index, and ferritin are quite independent between them. The Spearman's correlation coefficient between the values of hemoglobin and those of PCR of this group of patients was also examined, though no significant correlations were found (coefficient $0.143, \mathrm{p}<0.080$ ).

Table 2. Spearman'S correlation coefficient and $p$ values between levels of 25(OH)Vitamin D and the parameters of the table.

\begin{tabular}{llll}
\hline Variable & N & Coef. & p Value \\
\hline Age & 145 & 0.061 & 0.463 \\
Bone Alkaline Phosphatase & 145 & 0.135 & 0.106 \\
PINP & 145 & 0.025 & 0.769 \\
CTX & 145 & 0.032 & 0.703 \\
iPTH & 145 & -0.032 & 0.703 \\
BIO-PTH & 145 & -0.033 & 0.694 \\
Hemoglobin & 145 & 0.179 & 0.032 \\
Hematocrit & 145 & 0.163 & 0.051 \\
Urea & 145 & 0.122 & 0.144 \\
Creatinine & 145 & 0.168 & 0.044 \\
Total protein & 145 & 0.047 & 0.575 \\
Albumin & 145 & 0.17 & 0.041 \\
Iron & 145 & 0.249 & 0.003 \\
Iron saturation index & 145 & 0.253 & 0.002 \\
Calcium & 145 & 0.193 & 0.020 \\
Phosphorous & 145 & -0.17 & 0.041 \\
Total alkaline phosphatase & 145 & 0.06 & 0.473 \\
Serum CO ${ }_{2}$ & 143 & -0.122 & 0.146 \\
Cholesterol & 145 & 0.15 & 0.071 \\
Triglicérides & 145 & 0.018 & 0.826 \\
C-reactive protein & 142 & -0.053 & 0.535 \\
Prealbúmin & 114 & 0.092 & 0.33 \\
Ferritin & 145 & 0.165 & 0.047 \\
ProBNP & 143 & -0.007 & 0.929 \\
Tweak & 145 & 0.107 & 0.199 \\
FGF23 & 145 & -0.016 & 0.848 \\
Years in hemodiálisis & 141 & 0.216 & 0.010 \\
Hidroferol & 58 & 0.191 & 0.151 \\
Rocaltrol & 17 & 0.334 & 0.191 \\
Paricalcitol & 38 & -0.104 & 0.534 \\
Cinacalcet & 54 & 0.236 & 0.266 \\
Calcium chelants & & & 0.102 \\
\hline
\end{tabular}




\section{Discussion}

The results of this study carried out in hemodialysis patients show a strong, independent correlation between the levels of $25(\mathrm{OH}) \mathrm{D}$ and levels of hemoglobin, hematocrit, iron, iron saturation index, and ferritin. In other words, there exists a close relationship between the values of $25(\mathrm{OH}) \mathrm{D}$ and the degree of anemia of these patients that is not mediated by the levels of iron or ferritin, and it is a direct and independent correlation. As expected, a correlation between the levels of calcium (positive) and phosphorous (negative) and the levels of $25(\mathrm{OH}) \mathrm{D}$ in patients with $\mathrm{CKD}$ was also found, due to the role of $25(\mathrm{OH}) \mathrm{D}$ in the metabolism of calcium and phosphorous. The correlation with albumin was also expected due to the relationship between levels of 25 $(\mathrm{OH}) \mathrm{D}$ and the nutritional state of the patients.

Values corresponding to 145 patients in hemodialysis, 65.9 \pm 14.6 years, 74 males and 71 females and a mean time in hemodialysis of 3 years. Anemia is one of the main complications of the final stages of hemodialysis [8]. Anemia can lead to other comorbidities such as an increase of vascular complications and a decrease in quality of life and an increase of mortality. For this reason, knowledge of the mechanisms that can lead to anemia in these patients is of great interest.

Erythropoyetin (EPO) is the treatment of choice for anemia, and it must be administered to practically all patients during the final stages of chronic renal disease. However, these patients often develop a gradual lack of sensitivity to EPO administration, making dose increase necessary to maintain the desired levels of hemoglobin.

Different mechanisms that lead to the lack of response EPO have been suggested, such as iron deficiency, vitamin $\mathrm{B}_{12}$ deficiency, primary hyperparathyroidism, chronic inflammation, and cancer, but none of them fully explains this fact. In recent years, several works have suggested that vitamin D deficiency could be one of the risk factors involved in the lack of response to EPO $[4,9,10]$.

In a work published in 2015, Naini et al [11] administered $50000 \mathrm{UI}$ of vitamin D/week/12 weeks to 32 patients with hemoglobin $<11 \mathrm{~g} / \mathrm{dl}$ in end-stage hemodialysis. Another 32 patients were untreated. Mean hemoglobin levels were maintained between 9.91 and $10.14 \mathrm{~g} / \mathrm{dl}$ in the control group and between 9.93 and $11.1 \mathrm{~g} / \mathrm{dl}$ in the intervention group. A comparison between the required doses of EPO in the two groups showed a decrease in the treatment group $(p<0.001)$.

Similarly, in a 4-month study Kumar et al [12] treated 81 hemodialysis patients who had levels of 25(OH)D between 10 and $30 \mathrm{~g} / \mathrm{ml}$ with ergocalciferol (50 $000 \mathrm{UI} \times 4)$. Patients with levels $<10 \mathrm{ng} / \mathrm{ml}$ received $50000 \mathrm{UI} \times 6$. Mean levels of these patients were $15.3 \pm 10 \mathrm{ng} / \mathrm{ml}$ and were increased to $28.5 \pm 8.6 \mathrm{ng} / \mathrm{ml}$ after ergocalciferol. Mean basline dose of EPO was $21933 \mathrm{U} / \mathrm{month}$ and decreased to $18400 \mathrm{U} / \mathrm{month}$ after treatment. Due to this fact, these authors recommended a more aggressive supplementation with ergocalciferol to reach levels of $25(\mathrm{OH}) \mathrm{D}$ higher than $30 \mathrm{ng} / \mathrm{ml}$.

Kiss et al [8] analyzed data from 142 patients in hemodialysis. As in the present work, they found an independent and significant correlation between levels of $25(\mathrm{OH}) \mathrm{D}$ and hemoglobin and also an inverse correlation with the dose level of EPO required to maintain hemoglobin levels.

According to the results of this work, Patel et al [13] studied 1661 patients with renal disease. Levels of $25(\mathrm{OH}) \mathrm{D}$ and $1.25(\mathrm{OH})_{2} \mathrm{D}$ of these patients were independently correlated with decreased levels of hemoglobin and anemia.

Rianthavorn et al [14] demonstrated that the administration of ergocalciferol $+1.25(\mathrm{OH})_{2} \mathrm{D}_{3}$ reduced the doses of EPO necessary to treat children with CKD in stage 5.

Riccio et al [15] also demonstrated that paricalcitol exhibited beneficial effects on hemoglobin levels in patients with advanced-stage CKD, independently of other factors such as inflammation or PTH levels.

These results and those of other authors seem to demonstrate that vitamin D levels are associated with anemia, but the exact mechanism that causes this is unknown. Many of the studies that relate vitamin D deficiency and degree of renal anemia point to a prevalent role of inflammation [16]. VDR activations inhibit the expression of inflammatory cytokines of stroma and increase the release of IL10, exerting and anti-inflammatory activity and proliferative effects on erythroid progenitors. In patients with renal disease, vitamin D deficiency can stimulate to immune cells in the microenvironment of the bone marrow, to produce cytokines, causing a fail in erythropoyesis [17]. Kendrick et al [18] studied 16301 patients in the "National Health and Nutrition Examination Survey: NHANES III", observing that decreased levels of $25(\mathrm{OH}) \mathrm{D}$ and high of PCR were independently associated with low hemoglobin concentrations in patients with renal disease who did not require dialysis. In this study, a correlation between $25(\mathrm{OH}) \mathrm{D}$ levels and PCR was not found, a fact that seems to rule out the possibility that an increase of inflammation had produced anemia in our patients. On the other hand, the possible correlation between PCR and levels of hemoglobin was studied, and though a significant correlation was not found, the results nearly showed correlation $(\mathrm{p}<0.088)$, a fact that could indicate that inflammation could affect anemia, though in a way that is independent of vitamin D.

In the last phase of erythropoiesis, EPO is the main stimulus of erythroid maturation, and the lack of this hormone is the most prevalent cause of anemia in renal insufficiency [19]. Recent studies suggest that vitamin D plays an important role in the synthesis of EPO [13].

Another possible mechanism of anemia is that vitamin D directly stimulates erythroid precursors. A great number of VDR have been discovered in many no-renal tissues, including bone marrow [20, 21]. Normalization of levels of vitamin $\mathrm{D}$ in these tissues can provoke an adequate amount of substrate for the extra-renal hydroxylases, and these high concentrations of $1.25(\mathrm{OH})_{2} \mathrm{D}$ in hematopoietic tissues could directly activate precursor erythroid cells [22]. There are authors who postulate that the administration of $25(\mathrm{OH}) \mathrm{D}$ is more advantageous for improving anemia in patients with 
renal insufficiency than $1.25(\mathrm{OH})_{2} \mathrm{D}$ administration; this is achieved by administering substrate to the bone marrow to synthesize $1.25(\mathrm{OH})_{2} \mathrm{D}$ in an autocrine or paracrine way [23].

With respect to the mechanism behind the decrease in EPO activity in the case of vitamin $\mathrm{D}$, this deficiency could also be related to the production of proinflammatory cytokines that stimulate the synthesis of hepcidin. Hepcidin, a small polypeptide produced and liberated by the liver, is a mediator in the absorption and utilization of iron. Excessive hepcidin production contributes to the fact that there is not available iron for erythroid precursors and therefore to the development of anemia, although there is a sufficient quantity of EPO [24].

Some authors also point to an important role of PTH hypersecretion in renal anemia, which would have direct effects on endogenous EPO synthesis, bone marrow progenitors, and red cell survival [25]. The beneficial effects of vitamin D in controlling PTH hypersecretion could produce an improvement in the anemia of renal patients [25]. In our work, however, a correlation between $25(\mathrm{OH}) \mathrm{D}$ and PTH levels was not found, either with intact- or bio-PTH. Other authors suggest that the beneficial effect of vitamin D on anemia in renal patients is independent of PTH suppression [16].

\section{Conclusions}

In conclusion, levels of $25(\mathrm{OH}) \mathrm{D}$ are closely related, and seem to condition the degree of anemia of patients with chronic renal disease. As anemia is one of the main complications in the end stages of hemodialysis, it is of great importance to measure and maintain 25(OH)D levels in patients with renal failure in end stages, because this fact may reduce the anemia levels and the levels of EPO necessary to maintain hematocrit levels.

Acknowledgements.- This work has been supported by Roche España. We thank Maribel Villarino (Roche) for her kind help throughout the study.

\section{References}

[1] Rojas Rivera J, De la Piedra C, Ramos A, Ortiz A, Egido J. The spanding spectrum of biological actions of vitamin D. Nephrol Dial Transplant 2010; 25: 2850-2865.

[2] Melamed ML, Michos ED, Post W, Astor B. Calcifediol levels and the risk of mortality in the general population. Arch Intern Med 2008; 168: 1629-1637.

[3] Clayton P, Singer R. 25- Hydroxyvitamin D levels in prevalent Australian dialysis patients. Nephrology 2009; 14: 554-559.

[4] Holick MF. Vitamin D deficiency. N Engl J Med 2007; 357 : 266-281.

[5] Nykjaer A, Dragun D, Walther D, Vorum H, Jacobsen C. An endocytic pathway essential for renal uptake and activation of the steroid 25-(OH) vitamin D3. Cell 1999; 96: 507-15.
[6] Kidney Disease Improving Global Outcomes (KDIGO) CKDMBD Work Group. KDIGO Clinical practice guideline for the diagnosis, evaluation, prevention, and treatment of Chronic Kidney Disease-Mineral and Bone Disorder (CKD-MBD). Kidney Int Suppl 2009; 113: S1-S130.

[7] Dusso A, Tokumoto M: Defective renal maintenance of the vitamin D endocrine system impairs vitamin D renoprotection: a downward spiral in kidney disease. Kidney Int 2011; 79: 715-729.

[8] Kiss Z, Ambrus C, Almasi C, Berta K, Deak G, Horonyi P, Kiss I, Lakatos P, Marton A, Molnar MZ, Nemeth Z, Szabo A, Mucsi I. Serum 25(OH)-cholecalciferol concentration is associated with hemoglobin level and eritropoyetin resistance in patients on maintenance hemodialysis. Nephron Clin Prac 2011; 117: c373-c378.

[9] Ertürk S, Kutlai S, Karabulut HG, Keven K, Nergizoglu G, Ates K, Bokesoy I, Duman N. The impact of vitaminD receptor genotype on the management of anemia in hemodialysis patients. Am J Kidney Dis 2002; 40: 816-823.

[10] Blair D, Byham-Gray L, Lewis E, McCaffrey S. Prevalence of vitamin D deficiency and effects of supplementation with ergocalciferol in stage 5 chronic kidney disease patients. J Ren Nutr 2008; 18: 375-382.

[11] Naini AE, Hedaiati ZP, Gholami D, Pezeshki AH, Moinzadeh F. The effect of vitamin D administration on treatment of anemia in end-stage renal disease patients with vitamin D deficiency on hemodialysis: a placebo-controlled double-blind clinical trial. J Res Med Sci 2015; 20: 745-750.

[12] Kumar VA, Kujubu DA, Sim JJ, Rasgon SA, Yang PS. Vitamin D supplementation and recombinant human erythropoietin utilization in vitamin D-deficient hemodialysis patients. J Nephrol 2011; 24: 98-115.

[13] Patel NM, Gutierrez OM, Andress DL, Coyne DW, Levin A, Wolf M. Vitamin D deficiency and anemia in early chronic kidney disease. Kidney International 2010; 77: 715-720.

[14] Rianthavorn P, Boonyapapong P. Ergocalciferol decreases erythropoietin resistance in children with chronic kidney disease stage 5. Pediatr Nephrol 2013; 28: 1261-1266.

[15] Riccio E, Sabbatini M, Bruzzese D, Capuano I, Migliaccio S, Andreucci $\mathrm{M}$ et al. Effect of paricalcitol vs calcitriol on hemoglobin levels in chronic kidney disease patients: a randomized trial. PLoS One 2015; 10: e0118174.

[16] Icardi A, Paoletti E, De Nicola L, Mazzaferro S, Ruso R, Cozzolino M. Renal anemia and EPO hiporesponsiveness associated with vitamin D deficiency: the potential role of in inflammation. Nephrol Dial Transplant 2013; 28: 1672-1679.

[17] Davis SL, Litlewood TJ. The investigation and treatment of secondary anemia. Blood Rev 2012; 26: 65-71.

[18] Kendrick J, Targher G, Smits G, Chonchol M. 25hydroxyvitaminD deficiency and inflammation and their association with hemoglobin levels in chronic kidney disease. Am J Nephrol 2009; 30: 64-72.

[19] Nagaku M, Eckardt KU. Pathogenesis of renal anemia. Semin Nephrol 2006; 26: 261-268.

[20] Reichel H, Koeffler HP, Norman AW. The role of vitamin D endocrine system in health and disease. N EngIJ Med 1989; 320: 980-991. 
[21] Norman AW. Minireview: vitamin D receptor: new assignments for an already busy receptor. Endocrinology 2006; 147: 5542-5548.

[22] Sim J, Lac PT, Liu ILA, Megerditchian SO, Kumar V, Kujubu DA Rasgon SA. Vitamin D deficiency and anemia: a crosssectional study. Ann Hematol 2010; 89: 447-452.

[23] Lac PT, Choi K, Liu IA, Meguerditchian S, Rasgon SA, Sim JJ. The effects of changing vitamin D levels on anemia in chronic kidney disease patients: a retrospective cohort review. Clinical Nephrology 2010; 74: 25-32.

[24] Babit JL, Lin HY. Molecular mechanisms of hepcidin regulation: implications for the anemia of CKD. Am J Kidney Dis 2010; 55: 726-741.

[25] Brancaccio D, Cozzolino M, Gallieni M. Hyperparathyroidism and anemia in uremic subjects: a combined therapeutic approach. J Am Soc Nephrol 2004; 15: S21-S24. 